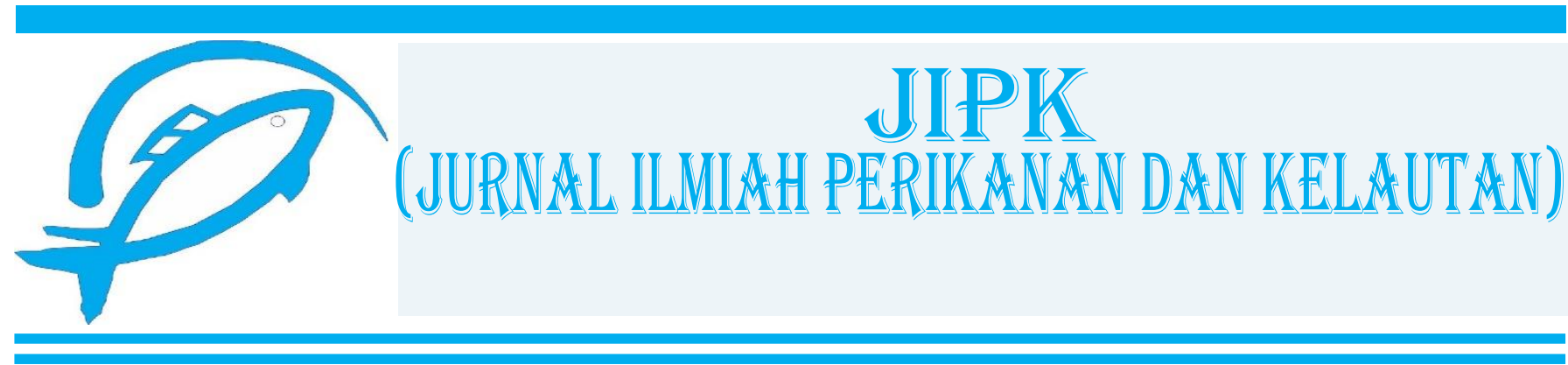

Short Communication

\title{
The Analysis of Morphological and Genetic Characteristics of Yellowstripe Scad from Muara Baru Modern Fish Market in North Jakarta
}

\section{Rahmat Sawalman* iD, Hawis Madduppa}

Department of Marine Science and Technology, Faculty of Fisheries and Marine Science, IPB University, Bogor, Jawa Barat, 16680. Indonesia

\section{OPEN $\rightarrow$ ACCESS \\ ARTICLE INFO}

Received: January 09, 2020

Accepted: September 26, 2020

Published: September 27, 2020

*) Corresponding author:

E-mail: rahmatsawalman24@gmail. com

\section{Keywords:}

Muara Baru

Modern Fish Market

Morphological Analysis

DNA Barcoding

Selaroides leptolepis

This is an open access article under the CC BY-NC-ND license (http://creativecommons.org/licenses/by-nc-nd/4.0/)

\begin{abstract}
Yellowstripe scad is one of the commercially important fish from the Carangidae family, which is marketed at Muara Baru Modern Fish Market, North Jakarta. Information regarding the presence of Selaroides leptolepis fish in the waters allows for effective conservation, and management of marine resources. A morphological identification of fish species is still considered inaccurate, so the molecular analysis is necessary. This study aims to identify commercially important fish species deriving from Muara Baru Modern Fish Market, North Jakarta, employing morphological, and molecular analysis. A total of 30 specimens were collected from the field. The morphological analysis utilized a visual identification method, and morphometric measurement, while molecular analysis with DNA barcoding employed the mitochondrial cytochrome oxidase subunit I (COI) gene. The results of the morphological analysis indicated that the fish species were yellowstripe scad (S. leptolepis). It also followed the results of molecular analysis of DNA barcoding that the fish was a S. leptolepis species. Therefore, the combination of morphological and genetic analysis has succeeded in identifying the fish species of S. leptolepis.
\end{abstract}

Cite this as: Sawalman, R., \& Madduppa, H. (2020). The Analysis of Morphological and Genetic Characteristics of Yellowstripe Scad from Muara Baru Modern Fish Market in North Jakarta. Jurnal Ilmiah Perikanan dan Kelautan, 12(2):308-314. http://doi. org/10.20473/jipk.v12i2.17241 


\section{Introduction}

Marine fishery resources in Indonesian waters cover $37 \%$ of the world's fish species. The potential marine fishery resources expanded in the territorial waters of Indonesia, and the waters of the Indonesian Exclusive Economic Zone (ZEE) are estimated at 12.54 million tons per year. It is reported that the total capture fisheries production has increased to 7.2 million tons (KKP, 2018).

Muara Baru Modern Fish Market is a marine and fishery business center in DKI Jakarta providing the fishery products which are highquality, safe for consumption, and at affordable prices. The fish in this market come from Lampung, Banten, West Java, Central Java, and East Java (along the north coast of Java Island). In 2018, the average number of fish traded in Muara Baru Modern Fish Market was 400 tons per day (KKP, 2018).

One of the fish species found in Muara Baru Modern Fish Market is yellowstripe scad (S. leptolepis). The fish is known as one of the pelagic fish from the family Carangidae and includes a commercially important fish (Kempter et al., 2015). The high market demand cannot be balanced by fish production in nature. According to (Sharfina et al., 2014), one of these fishing areas is Sunda Strait, where overfishing conditions are reported. The catch from these waters is marketed at Muara Baru modern fish market.

One of the important aspects of studying a biological species is the identification of the species itself. The accurate identification of fish species can assist in longterm fisheries management and will enhance the research on the ecological, ecosystem, and conservation aspects. Traditional fish identification method, such as morphological identification requires taxonomic expertise and are also considered inaccurate (Wang et al., 2018). However, currently, the molecular identification method of fish species has been developed and proven with more accurate results, namely the DNA barcoding method (Leray and Knowlton, 2015)

DNA barcoding is a sequencing based method for the species identification using a universal primer set to target a short, standardized genome region. One of the most frequently used genetic markers is the mitochondrial cytochrome oxidase subunit I (COI) gene. The COI gene is employed as an effective genetic marker for the identification and classification of various species using mitochondrial genes (Hebert et al., 2003).
According to Kamal et al. (2019), the DNA barcoding method with COI genetic markers can be utilized as an instrument in species utilization and protection. This research was conducted to apply morphological and DNA barcoding analysis to economically important fish $(S$. leptolepis) from Muara Baru Modern Fish Market, North Jakarta.

\section{Materials and Methods}

\subsection{Materials}

Materials used in this study included morphological analysis (caliper and analytical balance), and molecular analysis (surgical scissors, sample bottles, 96\% ethanol, gSYNCTM DNA Extraction Kit, DIAB Mastercycler DNA Engine Thermal Cycler, $1 \%$ agarose gel, GelRedTM (Biotium $\left.{ }^{\circledR}\right)$, and UV transilluminator).

\subsection{Methods}

\subsubsection{Morphological Analysis}

A total of $30(n=30)$ yellowstripe scads were measured for their length and weight. Meanwhile, their body characteristics and morphometrics were observed (Table 1). The length of the fish body was measured by utilizing calipers, while the body weight of the fish was measured by using analytical scales. The morphometric characters observed including Total Length (TL), Standard Long (SL), Head Long (HL), Head Depth (HD), Body Depth (BD), Caudal Peduncle Depth (CPD), Eye Diameter (ED), Eyes Interval (IE), Body Width (BW), Pre Pelvic Length (PPL), Pre Ventral Length (PVL), Pre Anal Length (PAL), Dorsal Basic Length (DBL), Ventral Basic Length (VBL), Pectoral Basic Length (PBL), Upper Caudal Length (UCL), Middle Caudal Length (MCL), Lower Caudal Length (LCL), Eyes Interval to Gill Cover (EIGC), and Anal Basic Length (ABL) (Figure 1).

\subsubsection{Molecular Analysis}

Regarding molecular analysis, the fish that had been morphologically analyzed were taken from the caudal fin (muscle tissue) using surgical scissors. Then the tissue was inserted into a sample bottle containing $96 \%$ ethanol solution. For one specimen of molecular analysis, $25 \mathrm{mg}$ of caudal fin's muscle tissue was isolated using the gSYNCTM DNA Extraction Kit. The mitochondrial cytochrome oxidase subunit I (COI) gene was directly amplified by PCR using a primer designed by Ward et al. (2005): FishF1 (5'TCAACCAACCACAA AGACATTGGCAC-3'); FishR1 (5'-TAGACTTCTGG GTGGCCA AAGAATCA3'). 
The amplification reaction was carried out in a total volume of $25 \mu \mathrm{l}$ containing $12.5 \mu \mathrm{l}$ of My Taq, $1.25 \mu 1$ of forward (F1) and reverse (F2), $9 \mu 1 \mathrm{ddH} 20$, $1 \mu \mathrm{l}$ of template DNA, respectively. The amplification was processed employing DIAB Mastercycler DNA Thermal Cycler Engine and followed the temperature profile: the initial stage was predenaturation at a temperature of $94^{\circ} \mathrm{C}$ for 30 seconds; followed by 38 cycles of each stage of denaturation $\left(94^{\circ} \mathrm{C}, 30\right.$ seconds), annealing $\left(50^{\circ} \mathrm{C}, 1\right.$ minute) and extension $\left(72^{\circ} \mathrm{C}, 1\right.$ minute); and a final extension at $72{ }^{\circ} \mathrm{C}$ for 7 minutes. PCR samples were filtered to obtain PCR results at $1 \%$ agarose gel. Furthermore, PCR results were visualized by electrophoresis in $1 \%$ agarose gel $\left(120^{\circ} \mathrm{C}, 20\right.$ minutes). The agarose gel was stained using GelRedTM (Biotium ${ }^{\circledR}$ ) and observed under a UV transilluminator. The amplification results were then sent to the 1st BASE® in Singapore for direct sequencing analysis.

\subsection{Data Analysis}

\subsubsection{Morphological analysis}

Fish samples were documented using an iPhone $6 s+$ camera, and analyzed using the ImageJ application. Morphological identification by matching it with the Market Fishes of Indonesia identification book White et al. (2013), and FAO (1974). Morphological visualization was digitized using CorelDraw X7 software. The result calculation of the morphometric analysis wascalculated using Ms. Excel 2010.

\subsubsection{Molecular Analysis}

The DNA sequences obtained were processed using the MEGA 6.0 application. The results acquired were then identified by equating the data available on GenBank at NCBI using the BLAST (Basic Local Alignment Search Tool) (https://www.ncbi.nlm.nih. gov), and compared with the reference sequence.

\section{Results and Discussion}

3.1 Morphology of Yellowstripe Scad

Table 1. Data of morphometric of Selaroides leptolepis $(\mathrm{n}=30)$

\begin{tabular}{clc}
\hline & Morphometric & Average \pm SD $(\mathbf{c m})$ \\
\cline { 2 - 3 } TL & Total Length & $11.76 \pm 0.73$ \\
SL & Standard Long & $9.93 \pm 0.76$ \\
HL & Head Long & $2.26 \pm 0.33$ \\
HD & Head Depth & $2.28 \pm 0.21$ \\
BD & Body Depth & $3.26 \pm 0.16$ \\
CPD & Caudal Penduncle Depth & $0.41 \pm 0.08$ \\
ED & Eye Diameter & $0.82 \pm 0.22$ \\
EI & Eye Interval & $1.02 \pm 0.11$ \\
BW & Body Width & $1.05 \pm 0.12$ \\
PPL & Pre Pelvic Length & $3.58 \pm 0.55$ \\
PVL & Pre Ventral Length & $3.24 \pm 0.36$ \\
PAL & Pre Anal Length & $5.70 \pm 0.48$ \\
DBL & Dorsal Basic Length & $2.76 \pm 0.54$ \\
VBL & Ventral Basic Length & $1.46 \pm 0.49$ \\
PBL & Pectoral Basic Length & $2.57 \pm 0.43$ \\
UCL & Upper Caudal Length & $2.18 \pm 0.23$ \\
MCL & Middle Caudal Length & $1.12 \pm 0.26$ \\
LCL & Lower Caudal Length & $2.12 \pm 0.25$ \\
EIGC & Eyes Interval to Gill Cover & $1.12 \pm 0.29$ \\
ABL & Anal Basic Length & $1.89 \pm 0.44$ \\
BW & Body Weight & $21.23 \pm 3.04 *$ \\
\hline
\end{tabular}

*) measured in gram 


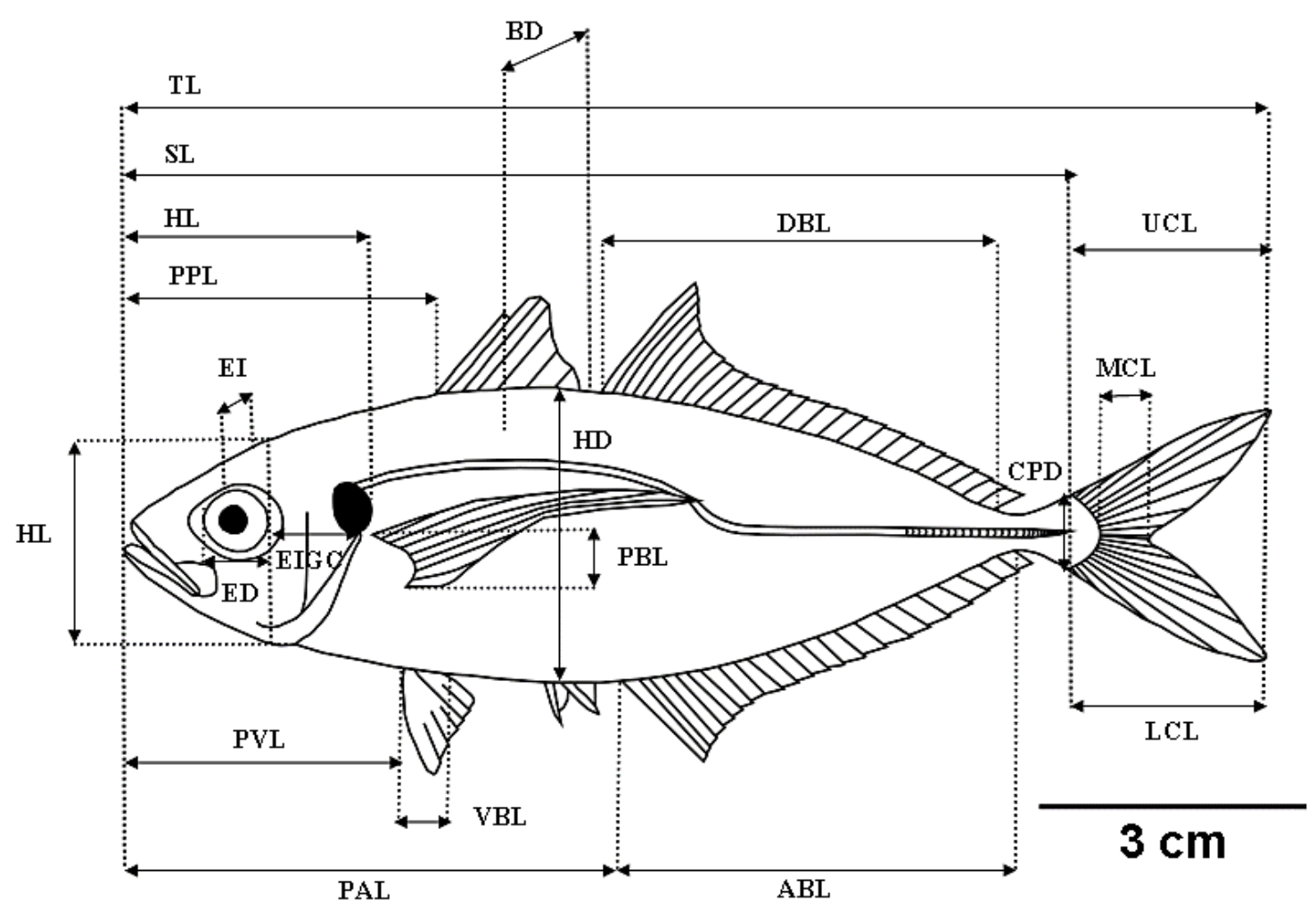

Figure 1. Morphometric of Selaroides leptolepis

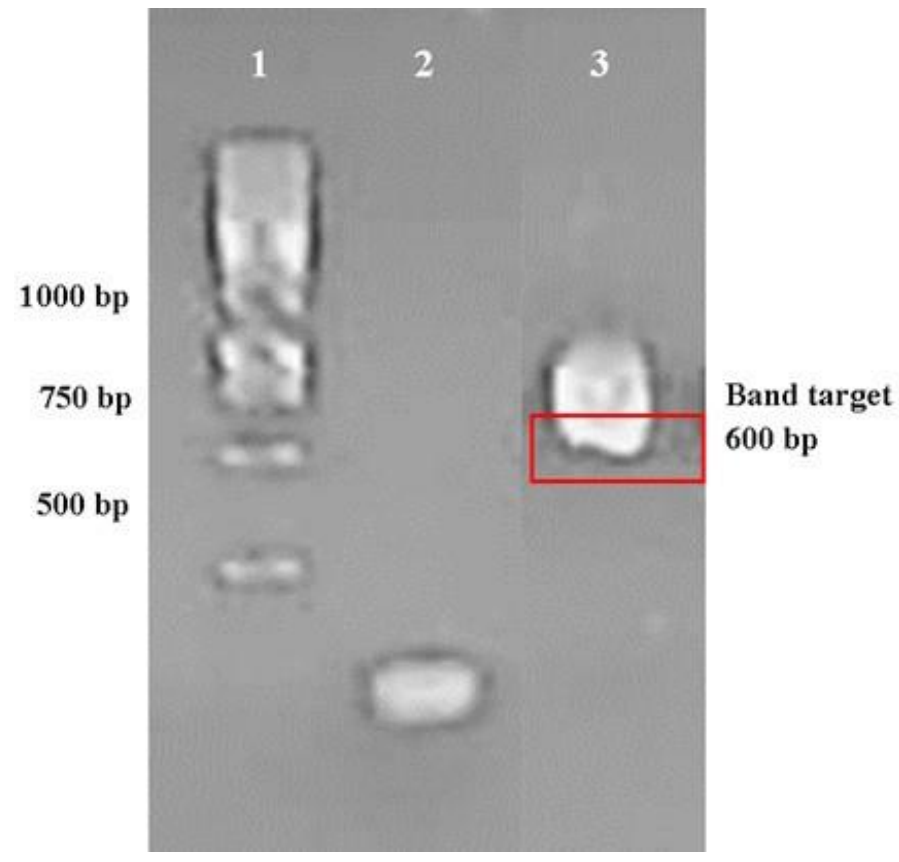

Figure 1. Electrophoresis results (1) DNA ladder; (2) negative control; (3) target sample
AGTAATTTGGTGCTTGAGCCGGAATAGTGGGA CAGCTTTAAGCTTACTCATCCGAGCAGAACTAAGCC AACCTGGCGCCCTTCTAGGGGACGAT CAG ATTTATAACGTA ATCGTTACGGCCCAC GCCTT-TGTA ATA AT CTTCTTTATAGTA AT GCCAATCATGATTGGTGGCTTCGGAAACTGACTCATCCCCCTAATGAT CGGAGCCCCCGACATGGCATTCCCCCGAATGAACA ATATGAGCTTCTGACTCCTTCCTCCTTCTTTCCTTCT TCTTCTGGCCTCTTCAGGGGTCGAAGCTGGAGCAG GAACTGGGTGAACAGTCTACCCCCCACTAGCCGGC AACCTGGCCCATGCTGGAGCATCCGTAGACTTAAC C AT CTTCTCCCTTCACTTAGCAGGTGTT-TC ATCC ATTCTAGGGGCC ATTA ACTTTATTACC-ACA ATTATCAAC ATGAAAC CCCCCGCAGTTTCA AT GTATCAA ATCCCACTATTCGTATGGGCCGTA-CTA ATTACGGCTGTTCTTCTCCTACTTTCACTTCCCGTC CTTGCAGCCGGG ATTACA ATGCTTCTCAC-AG ATCGAAATCTAAACACTGCCTTCTTCGACCCGGCA GGGGGTGGAGACCCA ATCCTTTAC CA A CA CCTCTTCTG ATTCTTTG G CCA CCAGAAAAGTC $\underline{\text { TAA }}$

Figure 2. The sequence of the COI gene sequence for the type Selaroides leptolepis from the Muara Baru Modern Fish Market, North Jakarta 
Table 2. BLAST of base nucleotide from GenBank

\begin{tabular}{|c|c|c|c|c|c|c|}
\hline Description & $\begin{array}{c}\text { Max } \\
\text { Score } \\
\end{array}$ & $\begin{array}{l}\text { Total } \\
\text { Score } \\
\end{array}$ & $\begin{array}{l}\text { Query } \\
\text { Cover }\end{array}$ & E value & Per. Ident & Accession \\
\hline $\begin{array}{l}\text { S. leptolepis voucher DBMF- } \\
\text { M77 cytochrome oxidase } \\
\text { subunit } 1 \text { (COI) gene, partial } \\
\text { cds; mitochondrial }\end{array}$ & 1188 & 1188 & $95 \%$ & 0.0 & $99.85 \%$ & HQ561005.1 \\
\hline $\begin{array}{l}\text { S. leptolepis isolate } \\
\text { FSCS085-06 cytochrome } \\
\text { oxidase subunit I (COI) gene, } \\
\text { partial cds; mitochndrial }\end{array}$ & 1182 & 1182 & $95 \%$ & 0.0 & $99.84 \%$ & EF607546.1 \\
\hline $\begin{array}{l}\text { S. leptolepis voucher DBMF- } \\
\text { M294 cytochrome oxidase } \\
\text { subunit } 1 \text { (COI) gene, partial } \\
\text { cds; mitochondrial }\end{array}$ & 1177 & 1177 & $94 \%$ & 0.0 & $99.84 \%$ & JX261019.1 \\
\hline $\begin{array}{l}\text { S. leptolepis isolate } \\
\text { FSCS179-06 cytochrome } \\
\text { oxidase subunit I (COI) gene, } \\
\text { partial cds; mitochondrial }\end{array}$ & 1177 & 1177 & $95 \%$ & 0.0 & $99.69 \%$ & EF607549.1 \\
\hline $\begin{array}{l}\text { S. leptolepis isolate SL4 } \\
\text { cytochrome oxidase subunit } \\
\text { I (COI) gene, partial cds; } \\
\text { mitochondrial }\end{array}$ & 1175 & 1175 & $94 \%$ & 0.0 & $99.84 \%$ & KJ502083.1 \\
\hline $\begin{array}{l}\text { S. leptolepis voucher } \\
\text { CEW0049 cytochrome c } \\
\text { oxidase subunit } 1 \text { (COI) } \\
\text { gene, partial cds; } \\
\text { mitochondrial }\end{array}$ & 1173 & 1173 & $98 \%$ & 0.0 & $98.64 \%$ & KU179063.1 \\
\hline $\begin{array}{l}\text { S. leptolepis voucher DBMF- } \\
\text { M475 cytochrome oxidase } \\
\text { subunit } 1 \text { (COI) gene, partial } \\
\text { cds; mitochondrial }\end{array}$ & 1173 & 1173 & $94 \%$ & 0.0 & $99.69 \%$ & JX261265.1 \\
\hline $\begin{array}{l}\text { S. leptolepis voucher } \\
\text { BBWC35 cytochrome } \\
\text { oxidase subunit } 1 \text { (COI) } \\
\text { gene, partial cds; } \\
\text { mitochondrial }\end{array}$ & 1171 & 1171 & $93 \%$ & 0.0 & $100.00 \%$ & KY372157.1 \\
\hline
\end{tabular}

Table 3. Comparison of long range of fish in several locations

\begin{tabular}{lcccc}
\hline \multirow{2}{*}{ Location } & \multicolumn{2}{c}{ Total Length $(\mathbf{m m})$} & \multirow{2}{*}{ Source } \\
\cline { 2 - 3 } & Min & Max & \\
\hline Fish Market of Tanjungpiang, Kepri & 145 & 310 & & (Febrianti et al., 2013) \\
Sunda Strait & 75 & 174 & & (Sharfina et al., 2014) \\
Pemalang Waters & 123 & 130 & & (Andriani et al., 2015) \\
Kei Islands & 100 & 247 & & (Supeni \& Almohdar, 2017) \\
Fish Market of Muara Baru, Jakarta & 106 & 129 & & This study \\
\hline
\end{tabular}


The morphological identification results noted that the species from the samples taken from the Muara Baru Modern Fish Market in North Jakarta is Selaroides leptolepis. The results were congruent with the morphological characteristics in the fish identification book by FAO (1974), stating that the morphological characteristics of the S. leptolepis were the lateral side of the eye to the caudal fin is golden yellow which is a distinctive characteristic of this species. Besides, the dorsal part is green and blue, the ventral remains are silvery, a slightly black spot on the operculum is spotted, and the caudal fin is yellow. In addition, according to (White et al., 2013), the fish have no teeth in the upper jaw, the rim (under the operculum) is smooth without papilla, the yellow line extends laterally, and it lives in a group at a depth of 050 meters in the soft substrates. It is distributed throughout the Indo-West Pacific waters.

The morphological characteristics of $S$. leptolepis in the form of length signified the differences in size from previous studies. The fish length size on Table 3 revealed that $S$. leptolepis caught in the Sunda Strait had the smallest size by $75 \mathrm{~mm}$, and the largest size by $310 \mathrm{~mm}$ found in the fish auction house of Tanjungpinang village unit cooperative. In this study, the range of the fish length size exposed that the size of the lengths between the minimum, and maximum fish were not overly different. The range of fish size could be said to be close to the homogeneous size. In other words, the fish size caught was close to the uniform length. Internal and external factors could attribute the difference in length size of S. leptolepis. Internal factors include heredity, sex, age, and disease, while external factors include food availability and water quality (Andriani et al., 2015). Additionally, the use of fishing gear that was not environmentally friendly as well as high exploitation pressures, such as fishing dominated by immature gonad fish or spawning, caused the differences in the fish length. Furthermore, the growth overfishing affected the recruitment process in the population (Agustina et al., 2015).

\subsection{Molecular Analysis}

The sequencing results obtained indicated a DNA length by $675 \mathrm{bp}$ (Figure 3), and the nucleotide composition of the S. leptolepis samples reached 187 or $27.70 \%$ Thymine, 197 (29.19\%) Cytosine, 161 or $23.85 \%$ Adenine, and 130 or $19.26 \%$ Guanine. The value of the cytosine nucleotide base was the highest, amounting to $29.19 \%$. The number of base pairing is in accordance with the COI primary target, which was $>600$ bp. In previous research by Jaafar et al. (2019), the number of base pairing in S. leptolepis from the sequencing results was $650 \mathrm{bp}$.
Although the number of base pairing in this study was different from previous studies, the fish species identified remained the same. According to Madduppa (2014), the different/varying lengths of base pairing were inflicted by the different number of samples.

Based on DNA barcoding analysis employing the COI gene in Selaroides sp., after being compared with the NCBI GenBank database, it is obtained the highest similarity percentage with the S. leptolepis species with the same Max score and total score of 1,188, Query cover 95\%, Evalue 0.0, and Per. Ident 99.85\%. According to Triandiza and Madduppa (2018), the Max score, and total score with the same value, Query cover nearly reached $100 \%$, Evalue was close to 0 , and Per. Ident approached $100 \%$ in each database, denoting the most similar GenBank sequences (Table 2).

The results of the molecular analysis suggested that the identified fish species was S. leptolepis. The results were in accordance with the morphological analysis conducted. Therefore, this species was genetically confirmed taxonomically, and supported morphological identification.

\section{Conclusion}

The results of morphological and genetic analysis employing DNA barcoding reveal the same species, namely S. leptolepis. Molecular test results utilizing COI (mitochondrial cytochrome oxidase subunit I) indicate similarity in species (Per. Ident $99.85 \%)$.

\section{References}

Agustina, S., Boer, M., \& Fahrudin, A. (2015). Population dynamics of layur fish (Lepturacanthus savala) resources in Sunda Strait. Marine Fisheries, 6(1): 77-85.

Andriani, N., Saputra, S., \& Hendrarto, B. (2015). Biological aspects and the level of utilization of yellow scad fish (Selaroides leptolepis) caught using cantrang nets in Pemalang Regency waters. Diponegoro Journal of Maquares, 4(4): 24-32.

FAO. (1974). Identification sheets for fishery purpose "Fishing area East Indonesia Ocean, Western Central Pacific". In Rome: UNDP/FAO Published (Vol. 4).

Febrianti, A., Efrizal, T., \& Zulfikar, A. (2013). Study of the condition of yellow scad (Selaroides leptolepis) based on the relationship between length and weight and condition factors in Natuna Sea landed at the Fish Market of Pelantar Kud Tanjungpinang. Jurnal umrah: 1: $1-8$. 
JIPK. Volume 12 No 2. November 2020 / The Analysis of Morphological and Genetic Characteristics of Yellowstripe Scad..

Hebert, P. D. N., Cywinska, A., Ball, S. L., \& DeWaard,J. R. (2003). Biological identifications through DNA barcodes. Proceedings of the Royal Society B: Biological Sciences, 270(1512): 313-321.

Kamal, M. M. , Hakim, A. A., , Butet, N. A., Fitrianingsih, Y., \& Astuti, R. (2019). Grouper species authentication based on gene markers MT-COI of Peukan Bada Waters, Aceh. Jurnal Biologi Tropis, 19(2): 116-123.

Kempter, J., Kielpinski, M., Panicz, R., Mikolajczyk, K., \& Keszka, S. (2015). Genetic Traceability of Selected Populations of The Yellow- stripe Scad, On The Analysis Of Microsatellite DNA Celfish Project - Part 3. Acta Ichthyologica Et Piscatoria, 45: 299-305.

KKP. (2018). Annual Report. 2018. Jakarta: Ministry of Marine Affairs and Fisheries.

Leray, M., \& Knowlton, N. (2015). DNA barcoding and metabarcoding of standardized samples reveal patterns of marine benthic diversity. Proceedings of the National Academy of Sciences of the United States of America, 112(7): 2076-2081.

Madduppa, H. (2014). Bioekologi dan Biosistematika Ikan Terumbu. Bogor: PT Penerbit IPB Press.

Jaafar, T. N. A. M., Taylor, M. I., Nor, S. A. M., Bruyn, M., \& Carvalho, G. R. (2019). Comparative genetic stock structure in three species of commercially exploited Indo-Malay Carangidae (Teleosteii, Perciformes). Journal of Fish Biology, 96(2).
Sharfina, M., Boer, M., \& Ernawati, Y. (2014). Population dynamics of yellowstripe scad (Selaroides leptolepis) in Sunda Strait. Marine Fisheries, 5(1): 101-108.

Supeni, E. A., \& Almohdar, E. (2017). The growth pattern of yellow scad (Selaroides leptolepis) in Southeast Maluku Regency. Fish Scientiae, 7(2): 105-112.

Triandiza, T., \& Madduppa, H. (2018). Application of morphological analysis and DNA barcoding in determining the type of porcelain crab (Pisidia sp.) originating from Tunda Island, Banten. Jurnal Sumberdaya Akuatik Indopasifik, 2(2): 81-90.

Wang, L., Wu, Z., Liu, M., Liu, W., Zhao, W., Liu, H., \& You, F. (2018). DNA barcoding of marine fish species from Rongcheng Bay, China. PeerJ, 6: $1-19$.

Ward, R. D., Zemlak, T. S., Innes, B. H., Last, P. R., \& Hebert, P. D. N. (2005). DNA barcoding Australia's fish species. Philosophical Transactions of the Royal Society B: Biological Sciences, 360(1462): 1847-1857.

White, W. T., Last, P. R., Dharmadi, R., F., Chodrijah, U., Prisantoso, B., Blaber, S. J. (2013). Market fishes of Indonesia (ACIAR Mono). Canberra: Australian Centre for International Agricultural Research. 